\title{
Plant serine proteases: biochemical, physiological and molecular features
}

\author{
Cecília M. Antão, F. Xavier Malcata* \\ Escola Superior de Biotecnologia, Universidade Católica Portuguesa, R. Dr. António Bernardino de Almeida, 4200-072 Porto, Portugal
}

Keywords: Enzyme; Mechanism; Substrate specificity; Function

\begin{abstract}
In the latest two decades, the interest received by plant proteases has been on the rise. Serine proteases (EC 3.4.21) -in particular those from cucurbits, cereals and trees-share indeed a number of biochemical and physiological features, that may prove useful toward understanding of several mechanisms at the subcellular level. This critical review focuses on the characterization of most plant serine proteases, and comprehensively lists information produced by more and more sophisticated research tools that have led to the current state of the art in knowledge of these unique enzymes.
\end{abstract}

\section{Introduction}

Peptidases, or peptide hydrolases, are enzymes able to hydrolyze peptide bonds. Peptidases comprise exopeptidases and endopeptidases; the former act only near the ends of polypeptide chains, whereas the latter act within the mentioned chains. In practical terms, "peptidases" and "proteases" are essentially equivalent to each other in terms of chemical features, with differences lying only on the size of the peptide chains used preferentially as substrates. For the sake of simplicity, the term "protease" will be used throughout this paper.

The enzyme subclass of proteases (EC 3.4) is in turn divided into sub-subclasses: enzymes belonging to subsubclass EC 3.4.21 (serine proteases) possess a Ser residue in the active site; those belonging to EC 3.4.22 (cysteine proteases) have a Cys residue instead; those belonging to EC 3.4.23 (aspartic proteases) depend on an Asp residue for their catalytic activity; and those belonging to EC 3.4.24 (metal-

Abbreviations: Clp, chloroplast protease; DFP, diisopropylfluorophosphate; HR, hypersensitive response; PCD, programmed cell death; PMSF, phenylmethylsulfonylfluoride; $p \mathrm{NA}$, para-nitroanilide; TE, tracheary element.

* Corresponding author. Fax: +35 1225090351 .

E-mail address: fxmalcata@esb.ucp.pt (F.X. Malcata). loproteases) use a metal ion (normally $\mathrm{Zn}^{2+}$ ) in their catalytic mechanism [17].

The aforementioned classification also conveys information on the nature of the enzymatic mechanism, as initially proposed by Dunn [16]: serine and cysteine proteases form covalent enzyme/substrate complexes, whereas aspartic and metalloproteases do not. In fact, as the former proteases have strong nucleophilic amino acid residues in their catalytic site, they perform a nucleophilic attack on the carbonyl group of the peptide bond; aspartic and metalloproteases, on the other hand, rely on general acid/base catalysis, which involves a water molecule [16].

Serine proteases were once thought to be rare in plants; in recent years, however, several of those enzymes have been isolated (and duly purified) from various plant species-in which they occur in distinct parts, ranging from the seeds to the latex and the fruits. They have indeed been found and extracted from the seeds of barley (Hordeum vulgare L. cv. Morex), soybean (Glycine max [L.] Merr.) and rice (Oryza sativa L.); from the latex of Euphorbia supina, dandelion (Taraxacum officinale Webb. S1.), African milkbush (Synadenium grantii Hook) and jackfruit (Artocarpus heterophyllus L.); from the flowers, stems, leaves and roots of Arabidopsis thaliana; from the storage roots of sweet potato (Ipomoea batatas [L.] Lam) and maize (Zea mays L.); from the sprouts of bamboo (Pleioblastus hindsii Nakai); from the leaves of tobacco (Nicotiana tabacum L.), common bean 
(Phaseolus vulgaris L. cv. Cesnjevec) and tomato (Lycopersicon esculentum L.); and from the fruits of melon (Cucumis melo L.), Cucurbita ficifolia L., osage orange (Maclura pomifera), suzumeuri (Melothria japonica [Thunb.] Maxim.), "Ryukyu white gourd" (Benincasa hispida var. Ryukyu), Japanese large snake gourd (Tricosanthes bracteata [Lam.] Voigt) and yellow snake gourd (Tricosanthes kirilowii Maxim. var. japonica [Miq.] Kitam).

The scope of this review encompasses biochemical and molecular approaches toward characterization of plant serine proteases-especially those most recently reported in the literature, as well as hypotheses on their possible roles in nature.

\section{Classification and mechanism}

Proteolytic enzymes that depend on a serine residue for catalytic activity are widespread in nature. On the basis of their three-dimensional structures, Rawlings and Barrett [45] have grouped serine proteases into six clans, according to their putative common ancestors. These authors claimed that the aforementioned enzymes have at least four separate evolutionary origins - which, nevertheless, may back up similar reaction mechanisms; most of them share a "catalytic triad" composed of Ser (a nucleophile), Asp (an electrophile) and His (a base). According to Dunn [16], the basic mechanism of action of serine proteases involves transfer of the acyl portion of a substrate to a functional group of the enzyme (a feature shared with other transferases). The two basic steps of catalysis by this group of enzymes thus include:

- first, the formation of an ester between the oxygen atom of serine and the acyl portion of the substrate-which produces a tetrahedral intermediate and releases the amino part of the substrate;

- and second, the attack of water on the acyl-enzyme intermediate, which breaks it down and releases the acidic product-while regenerating the original enzyme form.

This mechanism is depicted in detail in Fig. 1.

In recent years, most authors have replaced the term "clan" by "family", although the term "superfamily" is still in use [51]. Among other families, special mention is given to the subtilisin family - the second largest encompassing serine proteases. Recall that subtilisin is a serine protease initially isolated from Bacillus subtilis; the subtilisin family is widely distributed among eubacteria, archaebacteria, eukaryotes and viruses; moreover, the crystallographic structures of several of their members have already been resolved. The subtilisinlike proteases, sometimes named subtilases for short, may in turn be subdivided into two different subfamilies - the kexins and the pyrolysins; most mammalian subtilases belong to the former, whereas most plant subtilases purified to date are members of the latter [21]. Siezen and Leunissen [51] classified as subtilases the serine proteases from Lilium longiflorum, A. thaliana and Alnus glutinosa, the P69 protease from L. esculentum, cucumisin from $C$. melo, and the antifreeze protein af70 from Picea abies. A number of subtilases have

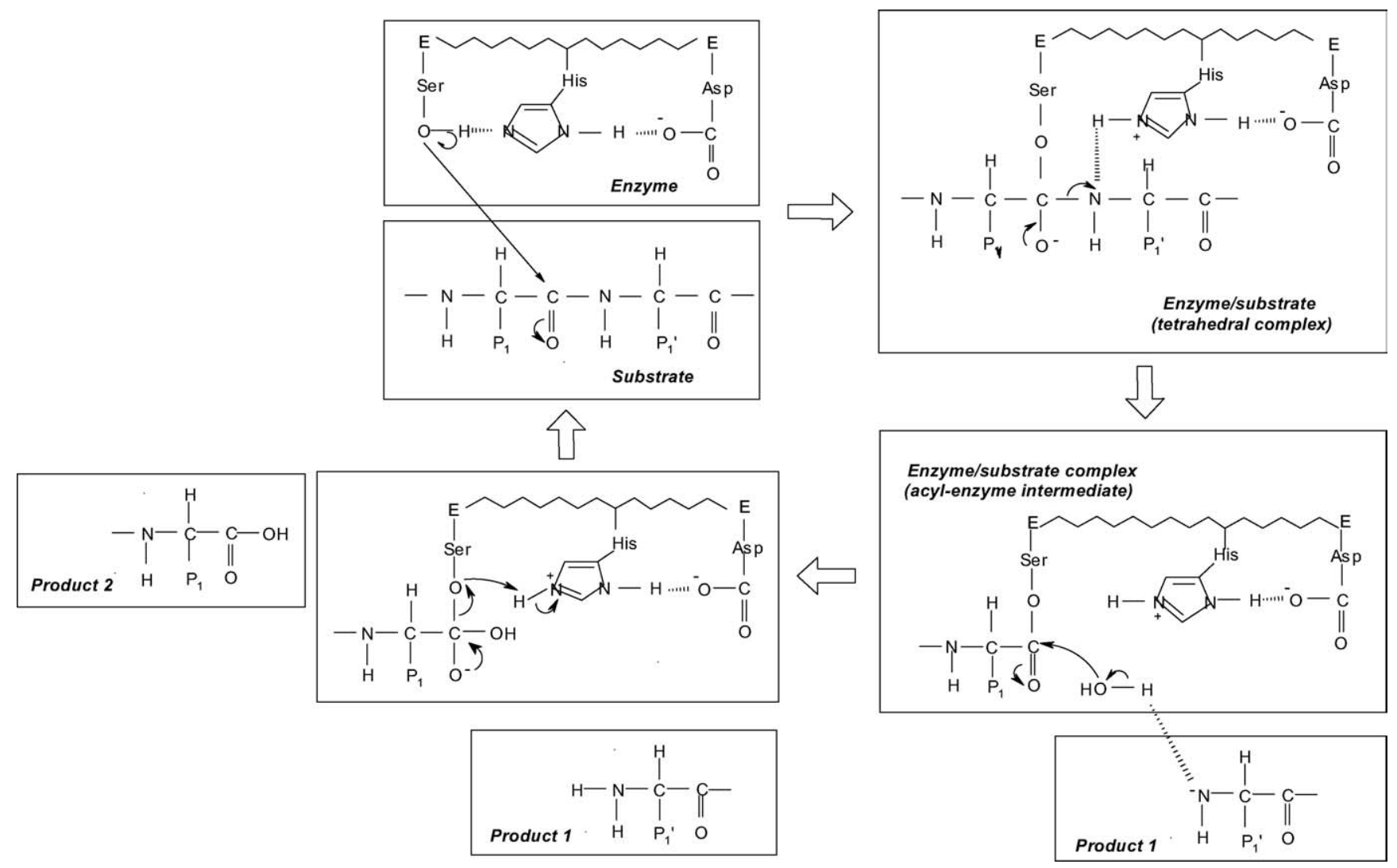

Fig. 1. Mechanism of reactions catalyzed by serine proteases. 
been isolated from various cucurbitaceous plants, yet cucumisin—an enzyme purified from melon (C. melo L.), remains the best characterized to date. Most subtilases are synthesized as pre-proenzymes, then translocated to a cell membrane guided by a pre-peptide (or signal peptide), and finally processed to the active form following cleavage of the pro-peptide [51]. The most striking feature of these enzymes is the high degree of sequence variability within their catalytic domains; apart from the «catalytic triad» Asp-His-Ser, all other residues may virtually be replaced by one or more distinct residues [51].

\section{Physicochemical properties}

Primary methods of purification of plant serine proteases often include ammonium sulfate precipitation, column chromatography and gel-filtration; secondary, yet more specific, techniques include affinity chromatography, chromatofocusing and hydrophobic interaction chromatography. As to their molecular weight, the plant serine proteases known at present vary from 19 to $110 \mathrm{kDa}$, but the majority lies between 60 and $80 \mathrm{kDa}$. The optimum $\mathrm{pH}$ for their activity is in the alkaline range ( $\mathrm{pH} 7-11)$; exceptions are hordolisin and SEP-1 from barley (optimum $\mathrm{pH}$ of 6 and 6.5, respectively), as well as Ara12 from A. thaliana RSIP from maize and protease $\mathrm{C} 1$ from soybean (which act best in the $\mathrm{pH}$ range 3.5-6.5). The optimum temperature is rather variable among these enzymes, from 30 up to $80{ }^{\circ} \mathrm{C}$-but most plant serine proteases usually act best in the range $20-50{ }^{\circ} \mathrm{C}$. Concerning inhibition of catalytic activity, the most commonly used compounds are diisopropylfluorophosphate (DFP) and phenylmethylsulfonylfluoridePMSF)howeverp-amidinophenymethanesulfonylfluoride (APMSF), 4-(2-aminoethyl) benzenesulphonylfluoride (AEBSF), antipain, aprotinin, chymostatin and soybean trypsin inhibitor (STI) are also frequently employed. Purification techniques of plant serine proteases are listed in Table 1.

The amino acid sequence is often used to compare serine proteases; e.g. in the case of cucumisin, the amino acid sequence Gly-Thr-Ser-Met in the vicinity of the Ser residue at its active site is identical to that of subtilisin [24]. Since cucumisin was the first serine protease isolated from a plant source, many other plant enzymes subsequently purified were compared to that enzyme from melon, namely in terms of amino acid sequence (Fig. 2).

Substrate specificity and kinetic parameters associated with catalytic performance are other features of extreme importance in attempts to characterize serine proteases; relevant information is listed in Table 2, which covers plant serine proteases studied during the latest three decades.

Some of the aforementioned enzymes are discussed below in a more detailed fashion - should information available justify it.

\section{Cucumisin}

This enzyme was purified for the first time in 1975 from the sarcocarp of melon, by Kaneda and Tominaga [26].
Uchikoba et al. [63] provided evidence for the broadness of its substrate specificity: peptidyl-p-nitroanilides and $\alpha$-chymotrypsin were both hydrolyzed by this enzyme. The catalytic activity of cucumisin was also assayed for using natural oligopeptides [26]. In particular, the specificity of cucumisin for oxidized insulin B-chain seemed to involve the carboxyl moiety of charged amino acid residues; its hydrolysis was faster than that of ovalbumin, superoxide dismutase or myoglobin [63]. The specificity of cucumisin has been further studied [2] via use of synthetic oligopeptides and peptidyl-para-nitroanilides ( $p$ NAs) as substrates; $\mathrm{P}_{1}{ }^{\prime}$-Ser, -Ala and-Gly substrates were readily hydrolyzed, so it seems that cucumisin prefers a small side chain at the $\mathrm{P}_{1}{ }^{\prime}$ position of the oligopeptide substrate. The value of $k_{\text {cat }}$ increased with the chain length of the peptide substrate: tetrapeptidyl- $p$ NA was cleaved ca. 25-fold faster than tripeptidyl- $p$ NA. In terms of $\mathrm{P}_{1}$-Ala substrates, Ala-Ala-Pro-Ala-Ser was the oligopeptide hydrolyzed fastest by cucumisin; $\mathrm{P}_{1}$-Ala, -Leu, -Phe and -Glu substrates were hydrolyzed much faster than $\mathrm{P}_{1}$-Lys and diaminopropionic acid substrates. On the other hand, the substrates containing Val and Pro at the $\mathrm{P}_{1}$ position were marginally hydrolyzed by cucumisin. According to Arima et al. [2], the specificity of cucumisin towards peptidyl- $p$ NAs is broad, but the preferential cleavage sites are next to hydrophobic amino acid residues at the $\mathrm{P}_{1}$ position.

The serine protease purified from muskmelon $(C$. melo ssp. melo var. Reticulatus Naud.) had relatively broad substrate specificity, but the preferential cleavage sites were the carboxyl-terminal sites of hydrophobic or acidic amino acid residues at the $\mathrm{P}_{1}$ position; the enzymatic properties of that protease are thus similar to those of cucumisin [29].

\section{Macluralisin}

A serine protease was isolated from the fruits of M. pomifera (raf.) Schneid, a perennial shrub commonly known as osage orange. This enzyme is a $65 \mathrm{kDa}$-glycoprotein, with a protein moiety of $50 \mathrm{kDa}$. Its $\mathrm{N}$-terminal sequence shares 33\% homology with the sequence of fungal subtilisinlike protease K. Macluralisin is similar to cucumisin, in terms of substrate specificity towards synthetic peptides and insulin B-chain [48].

\section{Taraxilisin}

A serine protease was purified from the latex of dandelion (T. officinale Webb s.1.) roots, and duly characterized. This enzyme possesses substrate specificity towards synthetic peptides and the insulin B-chain-which are both comparable to those of cucumisin and macluralisin [48].

\section{Serine proteases from other Cucurbitaceae}

Two serine proteases, A and B, were purified from the sarcocarp of yellow snake gourd (T. kirilowii) [59]. The optimum temperature (at $\mathrm{pH} 7.2$ ) for protease $\mathrm{A}$ was $60^{\circ} \mathrm{C}$, and 
Table 1

Overall biochemical characteristics of plant serine proteases, purified and studied during the latest 30 years

\begin{tabular}{|c|c|c|c|c|c|}
\hline Enzyme & Plant & Purification methods & $\begin{array}{l}\text { Molecular } \\
\text { weight }(\mathrm{kDa})\end{array}$ & $\mathrm{pI}$ & References \\
\hline $\begin{array}{l}\text { Cucumisin }(\mathrm{EC} \\
3.4 .21 .25)\end{array}$ & C. melo L. var. Prince & $\begin{array}{l}\text { Ion-exchange chromatography on CM-cellulose, gel-filtration } \\
\text { on Sephadex G-75 }\end{array}$ & 54 & - & $\begin{array}{l}\text { Kaneda and } \\
\text { Tominaga [26] } \\
\text { Yamagata et al. } \\
{[67]}\end{array}$ \\
\hline Serine protease & C. melo $\mathrm{L}$. & $\begin{array}{l}\text { Ammonium sulfate precipitation, gel-filtration, ion-exchange } \\
\text { chromatography }\end{array}$ & 26 & 9.5 & Noda et al. [38] \\
\hline Serine protease & $\begin{array}{l}\text { C. melo L. ssp. melo } \\
\text { var. Reticulatus }\end{array}$ & Ion-exchange chromatography on CM-Sepharose & ca. 62 & - & $\begin{array}{l}\text { Kaneda et al. } \\
{[29]}\end{array}$ \\
\hline Kiwano protease & Cucumis metuliferus & $\begin{array}{l}\text { Ammonium sulfate precipitation, ion-exchange } \\
\text { chromatography on CM-Sepharose }\end{array}$ & 78 & - & $\begin{array}{l}\text { Uchikoba et al. } \\
{[62]}\end{array}$ \\
\hline Serine protease & C. ficifolia & $\begin{array}{l}\text { Ammonium sulfate precipitation, gel-filtration on Sephacryl } \\
\text { S-300, ion-exchange chromatography on CM-Sepharose }\end{array}$ & 60 & - & $\begin{array}{l}\text { Curotto et al. } \\
{[14]}\end{array}$ \\
\hline RSIP & Z. mays L. & $\begin{array}{l}\text { Ion-exchange chromatography on Sepharose Q, gel-filtration } \\
\text { on Sephacryl S-200, chromatofocusing on Mono-P, } \\
\text { hydrophobic interaction chromatography on phenyl-Superose }\end{array}$ & $\begin{array}{l}59 \\
\text { (SDS-PAGE) } \\
62 \\
\text { (gel-filtration) }\end{array}$ & 4.55 & James et al. [22] \\
\hline Artocarpin & A. heterophyllus & $\begin{array}{l}\text { Ammonium sulfate precipitation, ion-exchange } \\
\text { chromatography on DEAE-cellulose }\end{array}$ & 79.5 & 6.3 & $\begin{array}{l}\text { Prasad and } \\
\text { Virupaksha [43] }\end{array}$ \\
\hline Proteases A and B & T. kirilowii & $\begin{array}{l}\text { Ammonium sulfate precipitation, ion-exchange } \\
\text { chromatography on CM-cellulose/CM-Sepharose, gel-filtration } \\
\text { on Sephadex G-75 }\end{array}$ & ca. 50 & - & $\begin{array}{l}\text { Uchikoba et al. } \\
\text { [59] }\end{array}$ \\
\hline Serine protease & T. bracteata & $\begin{array}{l}\text { Ion-exchange chromatography on CM-cellulose/ } \\
\text { CM-Sepharose, hydroxylapatite }\end{array}$ & ca. 67 & - & $\begin{array}{l}\text { Kaneda and } \\
\text { Uchikoba [27] }\end{array}$ \\
\hline Protease C1 & G. $\max (\mathrm{L}$.$) Merrill$ & $\begin{array}{l}\text { Ion-exchange chromatography on CM-Trisacryl } \\
\text { M/DEAE-Trisacryl M, gel-filtration on Sephadex G-75 }\end{array}$ & 70 & - & Qi et al. [44] \\
\hline Taraxilisin & $\begin{array}{l}\text { T. officinale Webb s.l. } \\
\text { (raf.) }\end{array}$ & $\begin{array}{l}\text { Ammonium sulfate precipitation, affinity chromatography on } \\
\text { Sepharose-Ala-Ala-Leu-mrp, gel-filtration on Superose 6R }\end{array}$ & 67 & 4.5 & $\begin{array}{l}\text { Rudenskaya et } \\
\text { al. [49] }\end{array}$ \\
\hline Serine protease & $\begin{array}{l}\text { Cudrania } \\
\text { cochinchinensis } \\
\text { (Lour.) Kudo et } \\
\text { Masam. }\end{array}$ & $\begin{array}{l}\text { Column chromatography on DEAE-cellulose/ } \\
\text { DEAE-Sepharose, gel-filtration on Sephacryl S-300 }\end{array}$ & 76 & - & $\begin{array}{l}\text { Uchikoba et al. } \\
{[58]}\end{array}$ \\
\hline MCA protease & N. tabacum & $\begin{array}{l}\text { Gel-filtration chromatography on Superose } 12 \mathrm{H} / \text { Superdex } 75 \text {, } \\
\text { anion-exchange chromatography on Sepharose Q-Hitrap }\end{array}$ & 68 & $5.8 \pm 0.1$ & $\begin{array}{l}\text { Messdaghi and } \\
\text { Dietz [36] }\end{array}$ \\
\hline Hordolisin & H. vulgare $\mathrm{L}$. & $\begin{array}{l}\text { Three steps of column chromatography, gel-filtration on } \\
\text { Superdex } 200\end{array}$ & 74 & 6.9 & Terp et al. [55] \\
\hline SEP-1 & H. vulgare $\mathrm{L}$. & $\begin{array}{l}\text { Chromatofocusing, ion-exchange chromatography on } \\
\text { DEAE-cellulose, CM-Macro Prep, gel-filtration }\end{array}$ & 70 & - & $\begin{array}{l}\text { Fontanini and } \\
\text { Jones }[18]\end{array}$ \\
\hline Serine protease & B. hispida var. Ryukuy & $\begin{array}{l}\text { Ion-exchange chromatography on } \\
\text { DEAE-cellulose/CM-Sepharose }\end{array}$ & ca. 67 & - & $\begin{array}{l}\text { Uchikoba et al. } \\
{[64]}\end{array}$ \\
\hline Protease B & E. supina & $\begin{array}{l}\text { Ion-exchange chromatography on DEAE-Sepharose, } \\
\text { gel-filtration on Sephacryl S-300 }\end{array}$ & ca. 80 & - & Arima et al. [4] \\
\hline Serine protease & P. hindsii Nakai & $\begin{array}{l}\text { Ammonium sulfate precipitation, ion-exchange } \\
\text { chromatography on CM-cellulose/ CM-Sepharose, } \\
\text { gel-filtration on Sephacryl S-200 }\end{array}$ & 82 & - & Arima et al. [3] \\
\hline Serine protease & $\begin{array}{l}\text { M. japonica (Thunb.) } \\
\text { Maxim. }\end{array}$ & $\begin{array}{l}\text { Ion-exchange chromatography on DEAE-Sepharose, } \\
\text { gel-filtration on Sephacryl S-300 }\end{array}$ & 61 & - & $\begin{array}{l}\text { Uchikoba et al. } \\
\text { [60] }\end{array}$ \\
\hline Plantagolisin & Plantago maior & $\begin{array}{l}\text { Ammonium sulfate precipitation, affinity chromatography on } \\
\text { bacitracin-Sepharose, ion-exchange chromatography on } \\
\text { Mono-Q }\end{array}$ & 19 & 5.0 & $\begin{array}{l}\text { Bogacheva et al. } \\
{[11]}\end{array}$ \\
\hline KLSP & $\begin{array}{l}\text { P. vulgaris L. } c v \text {. } \\
\text { Cesnjevec }\end{array}$ & $\begin{array}{l}\text { Ion-exchange chromatography, gel-filtration on Sephacryl } \\
\text { S-200 }\end{array}$ & 72 & 4.6 & $\begin{array}{l}\text { Popovič et al. } \\
\text { [42] }\end{array}$ \\
\hline
\end{tabular}


Table 1

(continued)

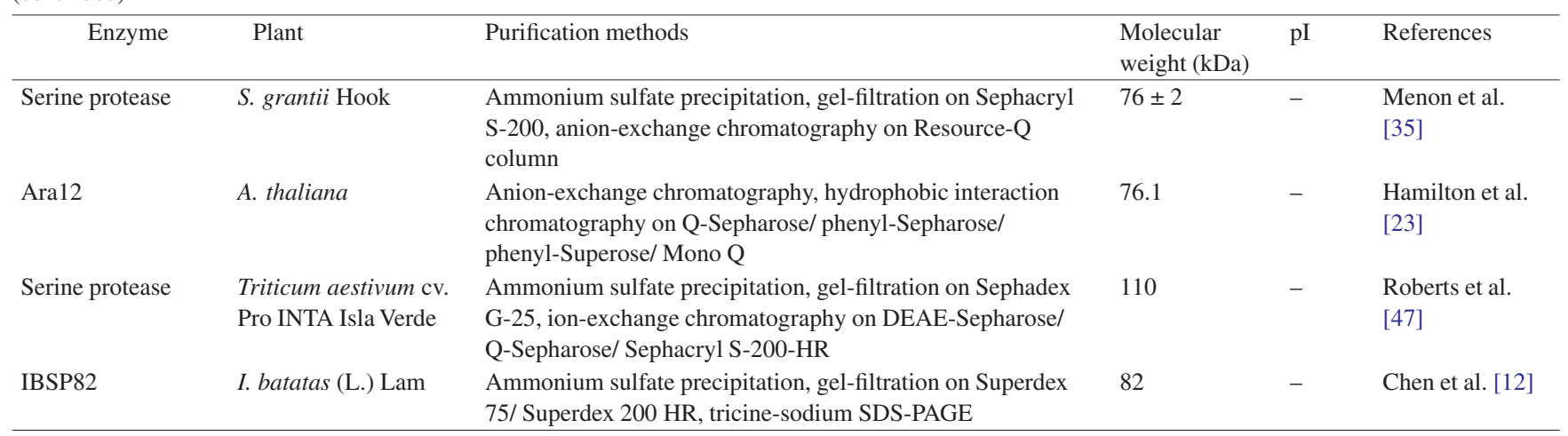

$70{ }^{\circ} \mathrm{C}$ for its B counterpart. Those authors concluded that such proteases are apparently similar to cucumisin.

Another serine protease similar to cucumisin was isolated from the sarcocarp of snake gourd (T. bracteata), and its substrate specificity was ascertained for oxidized insulin B-chain [27].

A protease was purified from the sarcocarp of wax gourd (B. hispida var. Ryukyu); the substrate containing Ala at the $\mathrm{P}_{1}$ position was the most appropriate for its proteolytic activity. The first 33 residues in the $\mathrm{N}$-terminus were sequenced, and it was shown that 25 thereof coincide with those of cucumisin; therefore, this enzyme was claimed as a cucumisin-like protease [64].

Finally, tropical squash (C. ficifolia) seeds possess serine protease, which hydrolyses casein and Suc-Ala-Ala-Pro-Phe$p \mathrm{NA}$ at $\mathrm{pH} 10.5$; oxidized insulin B-chain was also cleaved by this enzyme on several of its peptide bonds [15].

\section{Cucumisin-like serine proteases from other sources}

The latex of E. supina exhibits a strong caseinolytic activity, unlike its stems and leaves [4]; an enzyme was purified from the latex that, in spite of its broad specificity, cleaved preferentially the carboxylic moiety of peptide bonds involving hydrophobic amino acid residues. The 15 residues of the
$\mathrm{N}$-terminal sequence were determined, and six of them matched those in cucumisin.

From the sprouts of bamboo ( $P$. hindsii Nakai), another serine protease was purified-which cleaved peptide bonds involving uncharged residues at the $\mathrm{P}_{1}$ position; however, it preferred large hydrophobic and amide residues [3].

A serine protease with broad substrate specificity was also isolated from the fruits of $M$. japonica (a tree known as suzumeuri in Japan) [60].

\section{Serine proteases from cereals}

Two serine proteases were isolated from barley $(H$. vulgare L.): one of them, named hordolisin, was purified from green barley malt [53]. Its N-terminal amino acid sequence is homologous to that of cucumisin; in addition, there was a strong effect of substrate length upon the rate of cleavage by hordolisin. However, this enzyme has not proven important in the degradation of hordein storage proteins during barley grain germination. The other one was a subtilisin-like serine protease, isolated and purified from germinated seeds of barley - which was named SEP-1. Its amino acid sequence is similar to those of other plant subtilases-in particular those belonging to the cucumisin-like group [18].

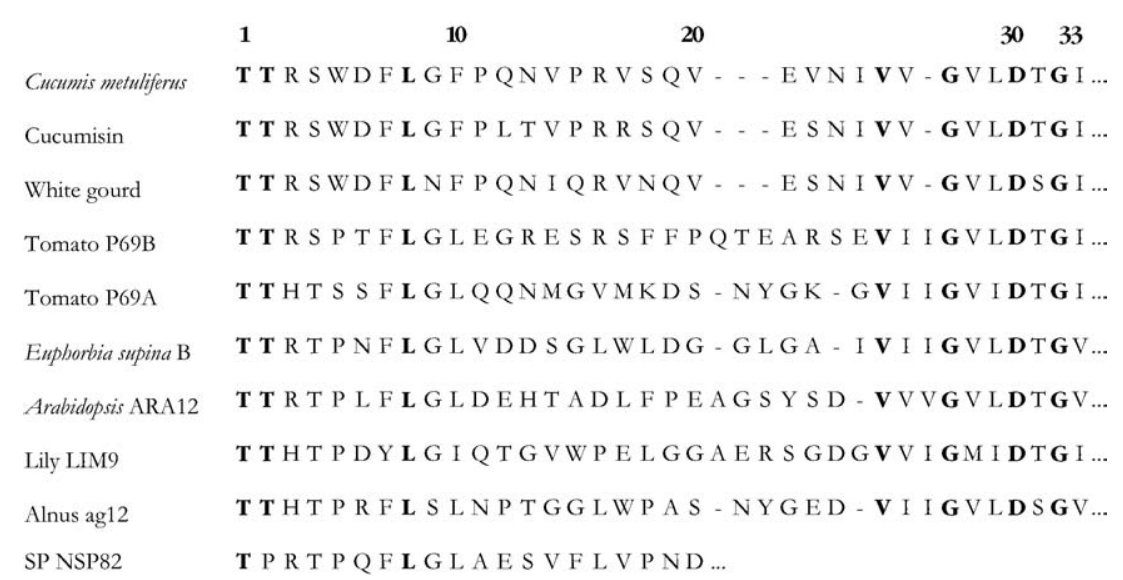

Fig. 2. Aligned list of the N-terminal amino acid sequences of various plant serine proteases. The amino acids are abbreviated to one-letter symbols, and identical amino acid residues in all sequences are represented in bold. The 30th amino acid residue is a predicted catalytic Asp residue (adapted from Uchikoba et al. [62,64] and Chen et al. [12]). 
Table 2

Kinetic characteristics, specificity and inhibitors of plant serine proteases, purified and studied during the latest 30 years

\begin{tabular}{|c|c|c|c|c|c|c|c|}
\hline Enzyme & Plant & $\begin{array}{l}\text { Optimum pH } \\
\text { (substrate) }\end{array}$ & $\begin{array}{l}\text { Optimum temperature } \\
\left({ }^{\circ} \mathrm{C}\right) \text { (substrate) }\end{array}$ & $K_{\mathrm{m}}(\mathrm{mM})($ substrate $)$ & Specificity & Inhibitors & References \\
\hline $\begin{array}{l}\text { Cucumisin (EC } \\
3.4 .21 .25)\end{array}$ & C. melo L. var. Prince & $\begin{array}{l}7.1 \text { (casein) stable at } \\
4-11\end{array}$ & 70 (casein) & 1.0 ( $\alpha$-chymotrypsin) & $\begin{array}{l}\text { Broad specificity for oli- } \\
\text { gopeptides and proteins }\end{array}$ & $\begin{array}{l}\text { DFP; partially inhibited } \\
\text { by } \mathrm{HgCl}_{2}\end{array}$ & $\begin{array}{l}\text { Kaneda and Tominaga } \\
\text { [26] Uchikoba et al. [63] } \\
\text { Kaneda et al. [28] }\end{array}$ \\
\hline Serine protease & C. melo $\mathrm{L}$. & - & _- & - & _- & DFP & Noda et al. [38] \\
\hline Protease D & $\begin{array}{l}\text { C. melo L. var. Inodorus } \\
\text { Naud }\end{array}$ & 11 (casein) & 35 (casein) & 0.91 (Z-Tyr-ONp) & $\begin{array}{l}\text { Broad specificity for } \\
\text { oligopeptides; preference } \\
\text { for carboxyl side of char- } \\
\text { ged amino acids; prefe- } \\
\text { rence for non-polar } \\
\text { amino acid or Pro at } \mathrm{P}_{2} \\
\text { position }\end{array}$ & DFP & Uchikoba et al. [61] \\
\hline Serine protease & $\begin{array}{l}\text { C. melo L. ssp. melo var. } \\
\text { Reticulatus }\end{array}$ & 11 (casein) & 35 (casein) & $\begin{array}{l}1.11 \text { (Ala-Ala-Pro-Dap- } \\
p \mathrm{NA} \text { ) }\end{array}$ & $\begin{array}{l}\text { Preference for hydropho- } \\
\text { bic or acidic amino acids } \\
\text { at } P_{1} \text { position }\end{array}$ & DFP & Kaneda et al. [29] \\
\hline Kiwano protease & C. metuliferus & $\begin{array}{l}8 \text { (Glt-Ala-Ala-Pro-Leu- } \\
p \mathrm{Na})\end{array}$ & $\begin{array}{l}20-40 \text { (Glt-Ala-Ala-Pro- } \\
\text { Leu- } p \mathrm{Na})\end{array}$ & - & $\begin{array}{l}\text { Broad specificity } \\
\text { towards peptidyl- } p \text { NAs } \\
\text { at } P_{1} \text { position; preference } \\
\text { for Pro at } P_{2} \text { position }\end{array}$ & DFP & Uchikoba et al. [62] \\
\hline Serine protease & C. ficifolia & 9.2 (azocollagen) & 55 (azocollagen) & - & - & PMSF & Curotto et al. [14] \\
\hline $\begin{array}{l}\text { MRP (proteinase } \\
\text { I) }\end{array}$ & Z. mays $\mathrm{L}$. & $\begin{array}{l}4 \text { (hemoglobin) } 9-10 \\
\text { (azocasein) }\end{array}$ & - & - & $\begin{array}{l}\text { Specificity towards pro- } \\
\text { tein substrates; prefe- } \\
\text { rence for N-terminal } \\
\text { sides with Ala residue }\end{array}$ & PMSF & $\begin{array}{l}\text { Goodfellow et al. [19] } \\
\text { Shannon and Wallace } \\
\text { [50] }\end{array}$ \\
\hline RSIP & Z. mays L. & $\begin{array}{l}6.5 \text { (casein, BSA, oval- } \\
\text { bumin) } 6.1 \text { (azocasein) }\end{array}$ & - & - & $\begin{array}{l}\text { Preference for hydropho- } \\
\text { bic amino acid residues } \\
\text { at } \mathrm{P}_{2} \text { and } \mathrm{P}_{3} \text { positions }\end{array}$ & $\begin{array}{l}\text { DFP; PMSF; trypsin } \\
\text { inhibitors; 3,4- } \\
\text { dichloroisocumarin }\end{array}$ & James et al. [22] \\
\hline Artocarpin & A. heterophyllus & $8.0($ casein $)$ & 60 (casein) & - & $\begin{array}{l}\text { Relatively broad specifi- } \\
\text { city towards peptides }\end{array}$ & PMSF & $\begin{array}{l}\text { Prasad and Virupaksha } \\
\text { [43] }\end{array}$ \\
\hline $\begin{array}{l}\text { Proteases A and } \\
\text { B }\end{array}$ & T. kirilowii & 10-11 (casein) & 35 (casein) & - & - & DFP & Uchikoba et al. [59] \\
\hline Serine protease & T. bracteata & 11 (casein) & 35 (casein) & $\begin{array}{l}0.74 \text { (Glt-Ala-Ala-Pro- } \\
\text { Leu- } p \text { NA) } 0.88 \text { (Suc- } \\
\text { Ala-Ala-Pro-Leu- } p \text { NA) }\end{array}$ & - & DFP & $\begin{array}{l}\text { Kaneda and Uchikoba } \\
\text { [27] }\end{array}$ \\
\hline Protease $\mathrm{C} 1$ & G. $\max$ (L.) Merrill & $3.5-4.5$ & - & - & $\begin{array}{l}\text { Preference for oligopep- } \\
\text { tides at Glu or Gln resi- } \\
\text { dues }\end{array}$ & PMSF & $\begin{array}{l}\text { Qi et al. [44] Barnaby et } \\
\text { al. [5] }\end{array}$ \\
\hline Macluralisin & $\begin{array}{l}\text { M. pomifera (raf.) } \\
\text { Scheid. }\end{array}$ & $\begin{array}{l}8.5 \text { (Glp-Ala-Ala-Leu- } \\
\mathrm{NHC}_{6} \mathrm{H}_{4} \mathrm{NO}_{2} \text { ) }\end{array}$ & $\begin{array}{l}58 \text { (Glp-Ala-Ala-Leu- } \\
\left.\mathrm{NHC}_{6} \mathrm{H}_{4} \mathrm{NO}_{2}\right)\end{array}$ & $\begin{array}{l}0.029 \text { (Glp-Ala-Ala-Leu- } \\
\mathrm{NHC}_{6} \mathrm{H}_{4} \mathrm{NO}_{2} \text { ) }\end{array}$ & $\begin{array}{l}\text { Fast hydrolysis of peptide } \\
\text { substrates of subtilisin }\end{array}$ & DFP & Rudenskaya et al. [48] \\
\hline Taraxilisin & $\begin{array}{l}\text { T. officinale Webb s.l. } \\
\text { (raf.) }\end{array}$ & $\begin{array}{l}8.0 \text { (Glp-Ala-Ala-Leu- } \\
p \mathrm{Na})\end{array}$ & $\begin{array}{l}40 \text { (Glp-Ala-Ala-Leu- } \\
p \mathrm{Na})\end{array}$ & $\begin{array}{l}0.37 \pm 0.06 \text { (Glp-Ala- } \\
\text { Ala-Leu- } p \mathrm{Na} \text { ) }\end{array}$ & $\begin{array}{l}\text { Similar to cucumisin; } \\
\text { best substrate Glt-Ala- } \\
\text { Ala-Pro-Leu- } p \text { Na }\end{array}$ & DFP; PMSF & Rudenskaya et al. [49] \\
\hline Serine protease & $\begin{array}{l}\text { C. cochinchinensis } \\
\text { (Lour.) Kudo et Masam. }\end{array}$ & 11 (casein) & 60 (casein) & - & - & $\begin{array}{l}\text { DFP; chymostatin; apro- } \\
\text { tinin }\end{array}$ & Uchikoba et al. [58] \\
\hline
\end{tabular}




\begin{tabular}{|c|c|c|c|c|c|c|c|}
\hline Enzyme & Plant & $\begin{array}{l}\text { Optimum pH } \\
\text { (substrate) }\end{array}$ & $\begin{array}{l}\text { Optimum temperature } \\
\left({ }^{\circ} \mathrm{C}\right) \text { (substrate) }\end{array}$ & $K_{\mathrm{m}}(\mathrm{mM})($ substrate $)$ & Specificity & Inhibitors & References \\
\hline Hordolisin & H. vulgare $\mathrm{L}$. & 6 & Stable up to 60 & $\begin{array}{l}4.7 \pm 0.6 \\
(\mathrm{XGAF} \downarrow \text { AFGZD X }=2- \\
\text { aminobenzoyl) } \\
3.24 \pm 0.33 \\
(\mathrm{XGAFF} \downarrow \mathrm{ZD} \mathrm{Z}=3- \\
\text { nitrotyrosine) }\end{array}$ & - & DFP & Terp et al. [55] \\
\hline SEP-1 & H. vulgare $\mathrm{L}$. & $\begin{array}{l}6.5 \text { (N-succinyl Ala-Ala- } \\
\text { Leu- } p \text { NA) }\end{array}$ & $\begin{array}{l}50 \text { (N-succinyl Ala-Ala- } \\
\text { Leu- } p \text { NA) }\end{array}$ & $\begin{array}{l}2.6 \text { (N-succinyl Ala-Ala- } \\
\text { Leu- } p \mathrm{NA})\end{array}$ & - & $\begin{array}{l}\text { PMSF; } p \text {-amidinophenyl } \\
\text { methanesulfonyl fluoride }\end{array}$ & Fontanini and Jones [18] \\
\hline Serine protease & B. hispida var. Ryukuy & $\begin{array}{l}\text { 7-11 (Ala-Ala-Pro-Ala- } \\
p \text { NA) }\end{array}$ & $\begin{array}{l}\text { ca. } 60 \text { (Ala-Ala-Pro-Ala- } \\
p \text { NA) }\end{array}$ & - & $\begin{array}{l}\text { Broad specificity } \\
\text { towards peptidyl-pNAs; } \\
\text { preference for small } \\
\text { hydrophobic amino acids } \\
\text { at } \mathrm{P}_{1} \text { position }\end{array}$ & DFP & Uchikoba et al. [64] \\
\hline Protease B & E. supina & 8 (casein) & - & - & $\begin{array}{l}\text { Broad specificity at } P_{1} \\
\text { position; preference for } \\
\text { C-terminal sides of } \\
\text { hydrophobic amino acids }\end{array}$ & DFP & Arima et al. [4] \\
\hline Serine protease & P. hindsii Nakai & $6.5-10.5$ & 30 & - & - & DFP & Arima et al. [3] \\
\hline MCA-protease & N. tabacum & $5-9$ & - & - & $\begin{array}{l}\text { MCA-Pro-Leu-Gly-Leu- } \\
\text { Dnp-Ala-Arg at Gly-Leu } \\
\text { bond }\end{array}$ & PMSF; cystatin & $\begin{array}{l}\text { Messdaghi and Dietz } \\
\text { [36] }\end{array}$ \\
\hline Serine protease & $\begin{array}{l}\text { M. japonica (Thunb.) } \\
\text { Maxim. }\end{array}$ & $\begin{array}{l}8 \text { (Glt-Ala-Ala-Pro-Leu- } \\
p \text { NA) }\end{array}$ & - & - & $\begin{array}{l}\text { Broad specificity at } \mathrm{P}_{1} \\
\text { position }\end{array}$ & DFP; PMSF & Uchikoba et al. [60] \\
\hline Plantagolisin & Plantago maior & $7-10$ & 40 & $\begin{array}{l}0.0619 \pm 0.0054 \text { (Suc- } \\
\text { Ala-Ala-Pro-Phe- } p \text { NA) }\end{array}$ & $\begin{array}{l}\text { Preference for hydropho- } \\
\text { bic amino acid, Pro, Arg } \\
\text { and Lys at } \mathrm{P}_{1} \text { position: } \\
\text { preference for Pro at } \mathrm{P}_{2} \\
\text { position }\end{array}$ & DFP; PMSF & Bogacheva et al. [11] \\
\hline KLSP & $\begin{array}{l}\text { P. vulgaris L. cv. Cesnje- } \\
\text { vec }\end{array}$ & 9.9 & - & $\begin{array}{l}351.5 \times 10^{-6} \text { (Boc-Val- } \\
\text { Gly-Arg-MCA) }\end{array}$ & $\begin{array}{l}\text { Preference for Arg at } P_{1} \\
\text { and } P_{2} \text { positions }\end{array}$ & $\begin{array}{l}\text { Antipain; aprotinin; chy- } \\
\text { mostatin }\end{array}$ & Popovič et al. [42] \\
\hline Serine protease & S. grantii Hook & 7.0 & 60 (azocasein) & $\begin{array}{l}2.5 \text { - fraction a) (azoca- } \\
\text { sein) } 4 \text { - fraction b) (azo- } \\
\text { casein) }\end{array}$ & - & $\begin{array}{l}\text { PMSF; diethyl pyrocar- } \\
\text { bonate }\end{array}$ & Menon et al. [35] \\
\hline Ara12 & A. thaliana & $\begin{array}{l}5.0 \text { (Abz- } \\
\text { QPFRQQAEZD) }\end{array}$ & 80 (FITC-labeled casein) & - & $\begin{array}{l}\text { Preference for Phe and } \\
\text { Ala at } \mathrm{P}_{1} \text { position, and } \\
\text { for Asp, Leu and Ala at } \\
\mathrm{P}_{1}^{\prime} \text { position }\end{array}$ & $\begin{array}{l}\text { DFP; PMSF; 4-(2- } \\
\text { aminoethyl) benzenesul- } \\
\text { phonylfluoride; STI }\end{array}$ & Hamilton et al. [23] \\
\hline Serine protease & $\begin{array}{l}\text { T. aestivum cv. Pro } \\
\text { INTA Isla Verde }\end{array}$ & $8-10$ & 60 & 1.18 (Suc-AAPF- $p$ NA) & - & Chymostatin; PMSF & Roberts et al. [47] \\
\hline IBSP82 & I. batatas (L.) Lam & 7.9 (bovine hemoglobin) & 40 & - & $\begin{array}{l}\text { Preference for hydropho- } \\
\text { bic and aromatic amino } \\
\text { acid residues at } P_{1} \text { posi- } \\
\text { tion }\end{array}$ & PMSF & Chen et al. [12] \\
\hline
\end{tabular}


Recently, two proteases were purified and characterized in oat (Avena sativa), following induction by a toxin (victorin) produced by a pathogenic fungus [13]. Their possible role in protein processing will be described in the next section.

\section{Serine proteases from legumes}

A serine protease that initiates the proteolysis of $\beta$-conglycinin storage proteins in soybean (G. $\max$ ) was isolated from seedling cotyledons [53]; by comparison of cleavage sites in $\beta$-conglycinin, it was shown that the $\mathrm{P}_{1}{ }^{\prime}$ and $\mathrm{P}_{4}{ }^{\prime}$ positions always contained either a Glu or an Asp residue, whereas the $P_{1}$ position was always occupied by either a Glu or a Gln residue. A fragment of this enzyme has been later cloned by RT-PCR [33]. The protease activity of developing and dry seeds was sensitive to PMSF and EDTA, as well as to synthetic poly-L-Glu-just like the purified protease $\mathrm{C} 1$. Those authors suggested that it was synthesized in a form that is active in vitro.

Another serine protease, designated as KLSP, was purified from mature leaves of common bean (P. vulgaris L.). The inhibition profile of this enzyme suggests that it is a member of the subtilase family [42]. Using different synthetic substrates, it was demonstrated that such a protease requires Arg in the $\mathrm{P}_{1}$ position for cleavage of the peptide bond; substrates with Gly or Phe in the $\mathrm{P}_{2}$ position led to higher $K_{\mathrm{m}}$ values. $\mathrm{N}$-terminal sequencing of KLSP showed how similar it is to subtilases from soybean and to cucumisin-like proteases.

\section{Serine proteases from chloroplasts and mitochond- ria}

The chloroplasts of higher plants contain proteases that are involved in protein degradation; however, the degree of characterization of such proteases is still poor. ClpP is a protein that shares similar characteristics with the proteolytic subunit of the bacterial ATP-dependent chloroplast protease (Clp) [39]. Recently, Peltier et al. [41] purified a Clp protease complex from distinct parts of $A$. thaliana, based on native mass, isoelectric point and mass spectrometry. This complex consisted of one to three copies of five different serine-type Clp proteases (Clp 1,3-6), and four non-proteolytic ClpR proteins (ClpR 1-4). Those authors observed that the ClpP/R proteins fit well together in a tetradecameric complex; moreover, the proteins ClpS 1,2, which are present only in land plants, interact closely with the core complex.

As to plant mitochondria, it was observed [41] that these organelles possess a single homo-tetradecameric ClpP2 complex — of ca. $320 \mathrm{kDa}$, deprived of any interaction with ClpR or ClpS proteins; in spite of the different composition of its plastid proteome, the Clp core constitution was apparently identical in the three plastid types studied (i.e. plastids of roots, flower petals and leaves). The structure of this complex conditioned its role in the cell-as emphasized in the next section.

\section{Metabolic function}

The involvement of plant serine proteases, namely subtilases, in many physiological processes has been well documented in the latest 5 years [40], although several authors $[9,18,21]$ have claimed that the roles of the vast majority of subtilisin-like proteases remain to be known. These include microsporogenesis, symbiosis, hypersensitive response (HR), signal transduction and differentiation, senescence and protein degradation/processing - which will be independently described in the subsections below.

\section{Microsporogenesis}

In the plant kingdom, subtilases are the family of serine proteases the function of which has been more thoroughly studied. The first role hypothesized for a subtilase was in fact microsporogenesis [31]; this physiological event takes place in higher plants, particularly in their anthers. Within these organs, specialized diploid cells become progenitor cells and undergo meiosis; some of these cells-microsporocytes, develop into the male gametophyte (pollen). The anthers possess tapetal cells that nourish the developing microsporocytes and also cell wall layers, thus providing physical support for the anther locule and carrying out dehiscence. Kobayashi et al. [31] constructed a cDNA library from microsporocytes, in the meiotic prophase, of lily (L. longiflorum), and some clones were selected; the corresponding transcripts accumulate at the early stages of meiosis-these transcripts showed clone-specific characteristics during meiosis and spore formation. The predicted gene products exhibited amino acid sequences similar to known gene products, including serine proteases from Bacillus sp. Since half of these gene products had hydrophobic N-terminal regions, the authors proposed that they could function as signal peptides-and concluded that such a species probably synthesizes serine proteases during microsporogenesis.

Taylor et al. [54] studied the association of microsporogenesis with a serine protease in lily; they identified, via immunoblotting, three meiotic proteins, which were differentially expressed in anthers during microsporogenesis. One of these proteins (LIM9) was purified and characterized to yield a molecular weight of $82 \mathrm{kDa}$; those authors then proposed that it was synthesized as a pre-proprotein, which later moved through the endoplasmic reticule and the Golgi body - where it received glycans, and was finally secreted into the anther locule. This protein attained the highest concentration as the microsporocytes reached the tetrad stage — which corresponds to late microsporogenesis. It was classified as a serine protease, by zymogram analyses and protein sequence comparison.

\section{Symbiosis}

The role of a subtilase in the symbiotic process has been investigated by few authors. From Alnus glutinosa, a tree com- 
monly known as European alder, a cDNA library from root nodules was constructed and, by means of in situ hybridization, it was shown that two of the nodule-specific cDNAs had the highest expression in infected cells; one of them, ag12, coded for a serine protease of the subtilisin family [46]. This actinorhizal nodulin gene was later shown to have strong homology to a subtilase gene, isolated and characterized from Casuarina glauca - an actinorhizal plant as well. Subtilases may thus participate in the infection process of plant cells during symbiosis [32].

\section{Hypersensitive response}

Serine proteases can be induced after a pathogen attack; this event leads to the HR - a complex, early defense process, which causes necrosis and cell death in order to restrict growth of the pathogen. It comprises an oxidative burst, which refers to the reactive oxygen species produced by cells undergoing HR. A pathogenic attack triggers a series of biochemical responses in plants-including the accumulation of a characteristic group of proteins called pathogenesis-related (PR) proteins.

This mechanism has been deeply studied by Tornero et al. [56] — who focused on the response of tomato plants to viroid infection, and who observed the induction of a set of PR proteins; one of them showed endoproteolytic activity and, owing to its molecular weight of $69 \mathrm{kDa}$, it was named PR-P69. This enzyme was synthesized as a pre-proprotein, and it shared homology with some domains of the subtilase family; moreover, part of its amino acid sequence was highly similar to the catalytic triad of subtilisin-like proteases. The activity thereof increased in the presence of $\mathrm{Ca}^{2+}$ ions, and such an enzyme accumulated in the intercellular spaces in leaves of viroid-infected plants. Moreover, those authors reported that PR-P69 was induced in the plant not only in response to such pathogens as fungi and nematodes, but also to ethylene and salicylic acid-molecules considered to mediate defense responses in plants.

Subsequently, biochemical, immunological and molecular approaches were used [57] to identify a cDNA encoding a protease from tomato plants (P69B), that resulted from the infection with citrus exocortis viroid. In spite of being closely related, in immunological terms as well as in amino acid sequence, to the previously identified subtilase PR-P69 (meanwhile renamed P69A), this new protease had $86 \%$ homology with the former enzyme. The authors thus suggested that P69B would be part of a gene family of plant Kex2/subtilisin-like proteases, and that it could be involved in several proteolytic reactions triggered by pathogenesis in plants. Given the degree of homology between P69A and P69B, coupled with the conservation of related genomic sequences, they speculated that these genes would probably arise through gene duplication events. Subtilases, could therefore, play similar biochemical roles in pathogenesis. This proteolytic system would take place in the extracellular matrix, since P69A protease had previously been [65], by immunocytochemical techniques, located in the apoplast.
Unlike all other members of the subtilase family, this P69 proteolytic system was induced during pathogenesis in plants. This fact, together with the extracellular localization of the mature enzymes, led Tornero et al. [57] to propose a novel interpretation of possible biological roles of subtilisinrelated proteases: these enzymes would mediate interaction of the plant cell surface with the extracellular environment.

\section{Signal transduction}

This event can be ascertained to serine proteases, and leads to hypersensitive cell death. It was established via use of a system, in which a xylanase from Trichoderma viride (TvX) induced an oxidative burst and eventual cell death in a culture of tobacco cells [68]; it was found that inhibitors of serine proteases inhibited TvX-induced cell death, hence suggesting that these enzymes might be part of a signaling pathway. This hypothesis was supported by a parallel study encompassing the fungus Cochliobolus victoriae, which causes a disease named victoria blight in oat [13]. A fungal toxin-victorin, induced a sensitive response in A. sativa, characterized by several morphological and biochemical events; one of these triggered events is Rubisco proteolysis-a process regulated by a signaling cascade, in which serine proteases are involved. Two of them proved to be cascadespecific, and showed homology with the amino acid sequence of plant subtilases. The authors showed that they were constitutive active enzymes - after induction by victorin or heat shock, these serine proteases remained in the extracellular fluid.

\section{Differentiation}

The function of serine proteases in the differentiation of specialized plant tissues or organs has recently been the focus of a few studies. Regarding the secondary vascular tissue, the putative role of serine proteases has been investigated both in Zinnia and in Arabidopsis spp.

In what concerns Zinnia elegans L., Groover and Jones [21] focused on the coordination between tracheary element (TE) differentiation, secondary cell wall synthesis, and programmed cell death (PCD) or apoptosis; these authors proposed that TE differentiation was mediated by a signaling process associated with secondary cell wall synthesis. Cell death correlated with production of a $40 \mathrm{kDa}$-serine protease, which would induce it; cell death required influx of $\mathrm{Ca}^{2+}$, and led to collapse of the hydrolytic vacuole-hence resulting in mixing of its content with that of the cytoplasm. Those authors presented a model to explain the occurrence of cell death — which would be coordinated with formation of a secondary cell wall, concomitant with secretion of the serine protease; the enzymatic activity would increase as the secondary cell wall was progressively synthesized, eventually reaching a critical point in the extracellular matrix that would trigger cell death, and thus stop wall synthesis (Fig. 3). Cysteine and serine proteases have been implied in the final pro- 


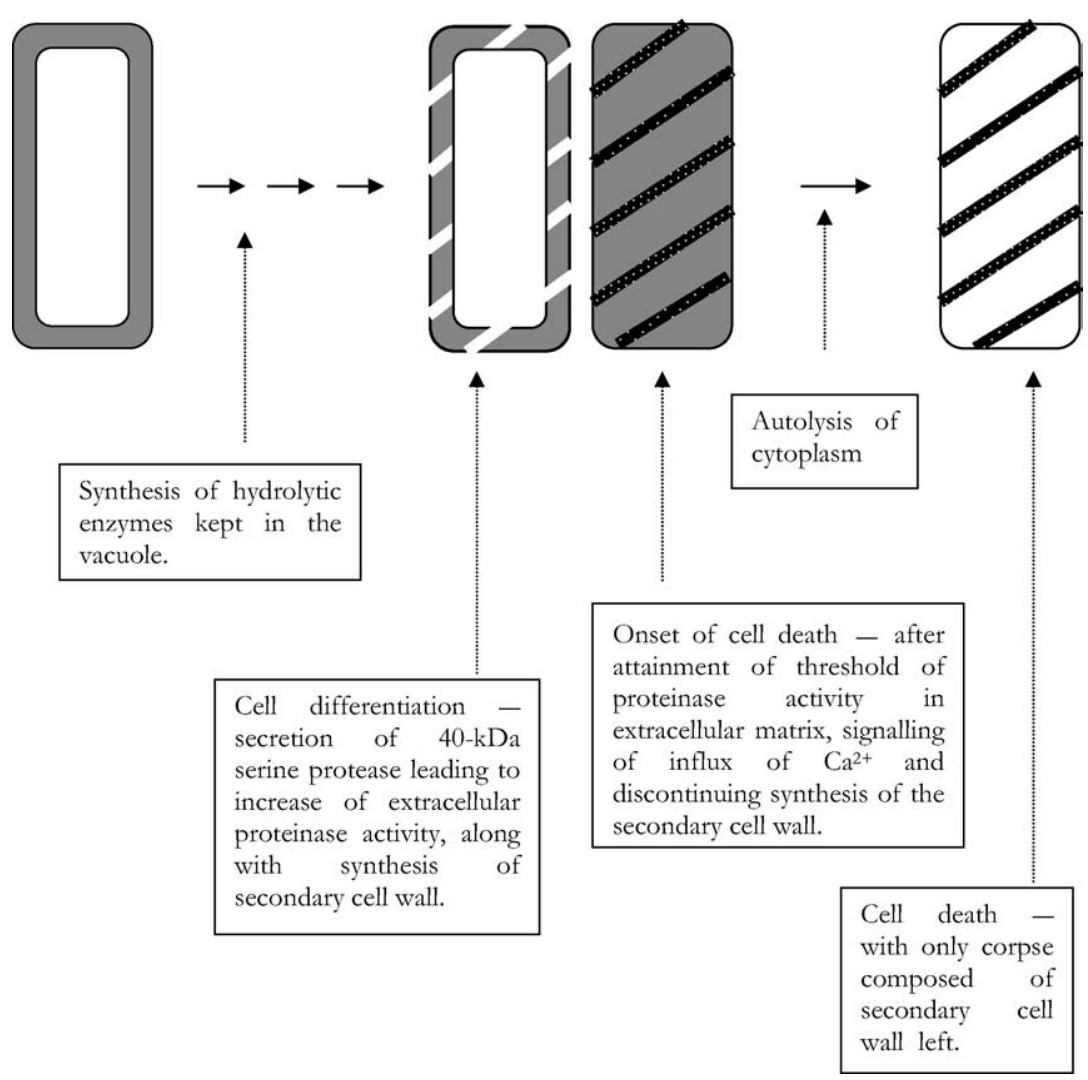

Fig. 3. Tentative model for the role of serine proteases upon secretion, on the secondary cell wall in higher plants (adapted from Groover and Jones [21]).

cess of xylogenesis (autolysis) in Z. elegans [69]; a serine protease, with an apparent molecular weight of $60 \mathrm{kDa}$, was strongly induced during in vitro TE differentiation.

The differentiation of the thick-walled parenchyma cells in soybean appears to be regulated by a seed coat-specific gene ( $\operatorname{scs} 1$ ); this gene is included in a family of genes that share a sequence similarity with subtilisin genes. By northernblot analysis, Batchelor et al. [6] reported that scs 1 RNA accumulated in seed coats up to a maximum concentration, just before the final steps of seed coat differentiation; moreover, in situ hybridization studies pointed at RNA accumulation in thick-walled parenchyma cells of seed coats. These cells play an essential role in the apoplastic translocation of nutrients, from the vascular tissue to the embryo.

The involvement of a serine protease in development of the stomatal structure was studied in A. thaliana [10]. Stomata are located in the epidermis of aerial plant organs, and control gas exchange, namely water release and carbon dioxide uptake, between leaves and atmosphere-via regulation of the aperture of pores, surrounded each by two guard cells. Their distribution is nonrandom and endogenous, and some environmental factors appear to control their density. In order to understand the molecular processes that modulate stomatal distribution, those authors isolated and examined $A$. thaliana mutants with modified stomatal characteristics. The sdd 1-1 mutant showed a considerable increase of stomatal density and the formation of clustered stomata, i.e. stomata that are not separated by intervening pavement cells. By mapbased cloning, the $s d d l$ gene was identified, and one found that it encoded a subtilisin-like serine protease related to prokaryotic and eukaryotic proteins; SDD1 might, therefore, be a processing protease which acts in signal mediation, that controls development of cell lineages thus leading to guard cell formation [10]. More recently, the localization and function of $s d d l$ was studied [20]; this gene is strongly expressed in stomatal precursor cells, and a negative feedback mechanism over the $s d d 1$ promoter was pointed out. The SDD1 protein was detected in association with the plasma membrane, but it might be exported to the apoplast-where it interacts with substrates. The proposed role of SDD1 would involve generation of a signal moving from stomatal meristematic cells to neighboring cells, and mediation of cell-cell interactions. The negative feedback of the $s d d l$ promoter was highlighted, among others, by observing its activity in the wild type and in the $s d d 1-1$ mutant. In the latter, the $s d d 1$ promoter was extremely active both in developing stomata and in leaf dividing cells, whereas in the wild type the leaves showed a transient weak expression of SDD1 [20]. These authors suggested that, in the wild type, the SDD1 protein caused repression of the $s d d l$ promoter in dividing cells of leaves, except the meristematic cells of stomata.

The formation of epidermal surface in embryos and juvenile plants was investigated, again using plants of the Arabidopsis genus as a model [52]. The cuticle-which covers the surfaces of land plants, is essential for water retention; consequently, when $A$. thaliana embryos and juvenile plants were homozygous for abnormal leaf shape 1 (ale) mutations, they presented defective epidermal surfaces, and showed, as a 
result, excessive water loss and fused organs in young plants. The ale 1 gene was isolated, and the predictive ALE1 primary structure was homologous to that of subtilisin-like serine protease. It was found that the aforementioned gene was expressed within some endosperm cells flanking the embryo, and within the young embryo itself; however, expression was not observed after germination. According to those authors, the putative ALE1 protease might affect the formation of cuticle on embryos and juvenile plants; an adequate cuticle is apparently needed to separate the endosperm from the embryo, and to prevent organ fusion [52].

\section{Senescence}

The association between proteolytic enzymes, organ senescence and TE differentiation has already been established, but the exact roles of those enzymes in these plant processes are not yet fully understood. However, expression of plant subtilases has been reported as relating to cell death: e.g. the lily subtilase, LIM9, accumulates in anther cells that undergo degeneration in the course of dehiscence; in addition, the existence of tomato subtilase LeSBT1 in roots and flowers may be correlated to PCD in these organs. The formation of lateral roots could be linked to PCD—and, in this process, an accumulation of subtilase mRNA has been noted [8].

In Arabidopsis sp., it was observed that, when senescence was delayed as a result of removing inflorescences, the roothypocotyl produced a considerable amount of secondary vascular tissue [70]. As peptidase zymograms were prepared from isolated xylem and phloem, different proteolytic enzyme profiles within the tissues could be revealed. cDNA libraries were duly constructed from xylem and bark, and screened for cDNAs molecules coding for cysteine, serine and aspartic proteases. From the xylem library, one possible subtilisin-like serine protease (XSP1) was identified for subsequent analysis. By using RNA gel blots, those authors found that this protease was expressed in the xylem but not in the bark; one may thus conclude that serine proteases are likely to play a role in the construction of xylem.

Plant senescence is, in general, understood as an internal process of programmed degeneration that leads to death. Proteases are believed to take part in senescence and, apparently, cysteine proteases are the most common proteolytic enzymes identified in this process [64]. In postharvest broccoli florets, Wang et al. [66] have associated class-specific proteases to senescence; using class-specific protease inhibitors and gelatin-PAGE, they suggested that serine protease activity plays a role in early stage (0-1 day after harvest, DAH) and late stage (4-5 DAH) of broccoli senescence; metalloproteases are apparently involved in early and intermediate stages (0-3 DAH) of senescence, whereas cysteine protease and aspartic proteases are active during the whole course of senescence.

\section{Protein degradation/processing}

The initiation of storage protein mobilization during early germination is another plant process in which proteases are undoubtedly important [37]. In dicotyledonous seeds, the major storage proteins are globulins (in most cereals, they are termed prolamins); such proteins accumulate during the middle and late maturation stages in protein bodies, which originate, in most species, from the protein storage vacuoles. During this storage period, the protein degradation and turnover are minimal, hence suggesting that proteins are somehow protected against proteolysis. The mobilization of storage proteins occurs in the course of seed germination and ultimate seedling growth. The synthesis of inactive precursors of proteases takes place in the rough endoplasmic reticule, from where they are transferred into protein bodies via the endomembrane system. Here, the enzymes are activated and protein degradation begins. During germination, limited amounts of storage proteins are degraded in specific places, and this event may be mediated by stored proteases; however, it remains unknown whether storage protein mobilization is controlled by de novo synthesized or by stored proteases in embryonic axes, and in which way early protein synthesis (during germination in axis and storage tissues) is dependent upon free amino acids produced by protein mobilization [37].

In this protein degradation/processing during storage, a number of aspartic and cysteine proteases have been implicated. Moreover, a serine protease - the soybean protease $\mathrm{C} 1$, may also be involved: it degrades $\beta$-conglycinin, a seed storage protein during germination and early growth [37]. However, it has recently been suggested [5] that its main role may be rather different; in fact, the soybean gene coding for protease $\mathrm{C} 1$ was expressed in leaves and also in stems of seedlings, but not in roots. Since its expression was enhanced by light, and since protease $\mathrm{C} 1$ was active during expansion of leaves, its main function may indeed be protein processing. An important proteolytic activity during tissue expansion has previously been mentioned [68] for MCA-protease in tobacco.

The aforementioned enzyme SEP-1 from barley is not likely involved in storage protein degradation; in fact, it is present in resting seeds, and its activity increases throughout germination in all malted barley tissues but the endosperm [18]. In maize roots, a vacuolar serine protease (RSIP) was strongly induced following glucose starvation; it might, therefore, be involved in the degradation of cellular proteins [22].

Activity of serine proteases associated to specific organelles has already been reported; Peltier et al. [41] proposed that plastid proteolysis was regulated by the Clp machinery, via processes involving substrate-recognition and mediated interaction of chaperone-like molecules (namely Clp S1,2) with the $\mathrm{ClpP} / \mathrm{R}$ core. Therefore, it appears that serine-type proteases of plastids participate in the regulation of these organelles [41]. The expression of ClpP proteases is partially stimulated by light; Adam [1] suggested that these enzymes could play a role in the degradation of mistargeted proteins, and also be involved in the protein importing process.

Finally, a serine protease has been described [30] in association with the membrane of plant mitochondria in spinach 
leaves; its proteolytic activity was ATP-dependent, and consisted on the degradation of newly imported precursor proteins.

\section{Gene identification}

Following identification of P69A and P69B in tomato, Jordá et al. [24] carried out the screening of a genomic library from this plant with a cDNA probe-encoding subtilase P69A. The result was the isolation of a cluster of genomic clones, comprising a group of four different subtilisin-like protease genes (P69A, P69B, P69C and P69D). Although they were all closely related (79-88\% identity), the four genes showed different transcriptional regulation and expression patterns. Despite their distinct expression profiles during development, the expression of both $P 69 A$ and $P 69 D$ was constitutive, whereas the expression of $P 69 B$ and $P 69 C$ occurred during infection with Pseudomonas syringae and was upregulated by salicylic acid [24]. These authors proposed that such four proteases could be part of a complex gene family of plant subtilases - according to what they had earlier suggested regarding P69A and P69B. Those four P69-like proteases would thus play a role in several specific proteolytic processes, that occur in the plant during development and/or pathogenesis. Later on, Jordá et al. [25] characterized two new members of the P69 family of subtilases from tomato plants, which were named P69E and P69F. Notwithstanding the fact that they are organized in a cluster and in a tandem, they are differently regulated; $p 69 E$ mRNA is expressed only in roots, whereas $P 69 F$ mRNA is expressed only in hydathodes. Those authors compared all P69 amino acid sequences, gene structures, expression profiles and clustered organization, and accordingly proposed a working model for the P69 gene family evolution.

Still regarding tomato plants, Meichtry et al. [34] suggested a classification of the gene family of subtilases in $L$. esculentum. This family would comprise 15 members and, based on sequence comparison, tomato subtilases could be divided into five distinct subfamilies. The authors provided evidence that single genes exist for LeSBT1, LeSBT2 and tmp, whereas five and six genes were found in the LeSBT3/4 and P69 subfamilies. Using northern-blot analysis and/or primer extension experiments, the expression of subtilase genes was confirmed at the mRNA level. These five subtilase subfamilies showed a distinctive pattern of expression in tomato organs.

In soybean, Beilinson et al. [9] identified two subtilisinlike proteases, named SLP-1 and SLP-2. The first was present in seed coats, and was only partially purified; another SLP gene was then revealed by DNA blot analysis. The gene $S L P-2$ was also cloned and further studied; it was identified in both developing seeds and mature plants, even though $S L P-1$ could only be detected during early development of soybean seeds. The function of each of these genes still remains to be known.

The S8 family of serine proteases in Arabidopsis sp. has recently been reviewed [7]. These authors drew a phyloge- netic tree of the 54 Arabidopsis subtilases based on their corresponding genes; such subtilases were compared to other plant S8 proteases from melon, lily, tomato and soybean. Although molecular processes alone can hardly explain evolutive divergences between those enzymes, genomic clustering of these subtilases unfolded different structures for some of them [7]. Consequently, said enzymes would likely show a broad functional diversity.

\section{Conclusions}

Plant serine proteases are widespread among taxonomic groups, from trees and crops to legumes and herbs. They are also present in almost all plant parts, but seem to be more abundant in fruits. As to biochemical features, a great many of them are active at $40^{\circ} \mathrm{C}$ and above; however, optimum $\mathrm{pH}$ values vary greatly, from acidic to neutral and alkaline environments. In general, they show broad substrate specificity for proteins - and casein in particular, and for oligopeptides, although many studies have been conducted using only synthetic substrates. Most serine proteases are inhibited by classspecific inhibitors, such as DFP and PMSF. Despite the relatively well established kinetic knowledge on those enzymes, very few biotechnological applications have been tested using them as biocatalysts.

These enzymes have been associated to a number of physiological roles in the plant cell, namely: as signal peptides in microsporogenesis; in symbiosis; induced after a pathogen attack, thus leading to HR; or as part of a signaling pathway regulating Rubisco proteolysis, which is triggered by a fungal toxin. Differentiation of specialized plant tissues, such as stomata, TEs and secondary cell wall, is also dependent on the production of specific serine proteases. They might be

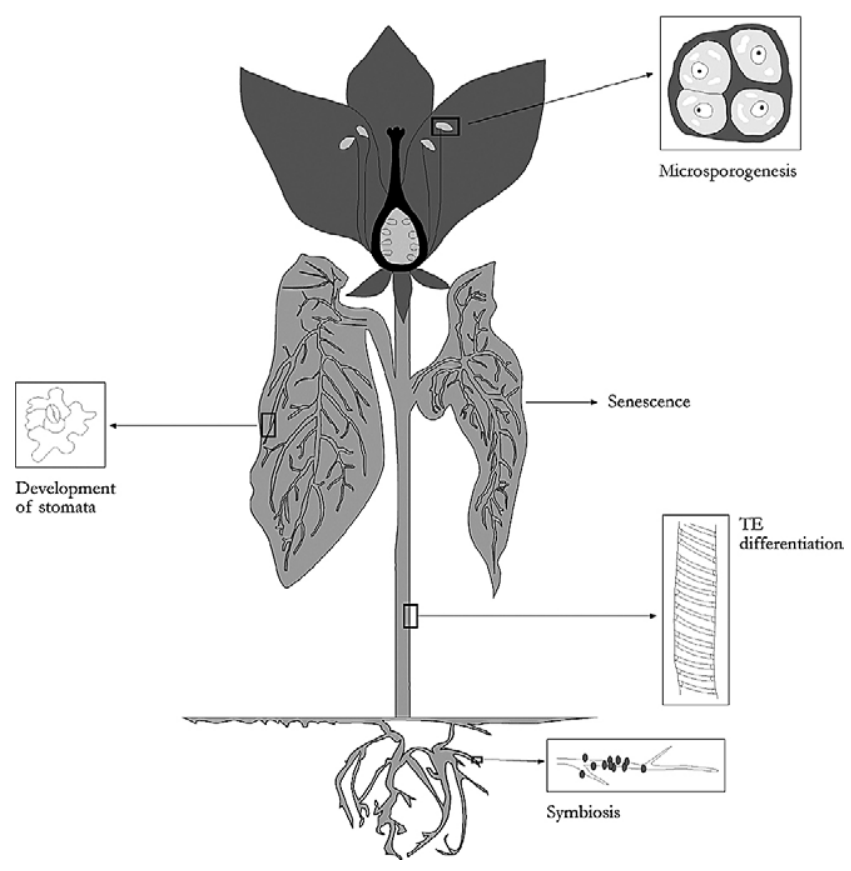

Fig. 4. Selected metabolic functions of serine proteases. 
involved in protein degradation or processing during early germination and plastid proteolysis, and in degradation of precursor proteins in plant mitochondria. These roles are summarized in Fig. 4.

However, knowledge of the physiological roles of serine proteases in plant cells still needs further research. Use of specific antibodies associated to well-studied biochemical methods would be of great help toward a better understanding of their function inside the cell-encompassing the apparent diversity of roles in the plant as a whole.

\section{Acknowledgements}

The authors acknowledge Dr. Susannah Gal (c/o Binghamton University, New York, USA) for critical reading of this manuscript, and Dr. César Ferreira and Mrs. Assunção Teles for technical editing support. Author C. M. Antão is grateful to Fundação para a Ciência e a Tecnologia (Portugal), for a Ph.D. fellowship (SFRH/BD/8525/2002).

\section{References}

[1] Z. Adam, Protein stability and degradation in chloroplasts-a minireview, Plant Mol. Biol. 32 (1996) 773-783.

[2] K. Arima, H. Yonezawa, T. Uchikoba, M. Shimada, M. Kaneda, Cleavage specificity of cucumisin, a serine protease, with synthetic substrates, Phytochemistry 54 (2000) 451-454.

[3] K. Arima, T. Uchikoba, H. Yonezawa, M. Shimada, M. Kaneda, Isolation and characterization of a serine protease from the sprouts of Pleioblastus hindsii Nakai, Phytochemistry 54 (2000) 559-565.

[4] K. Arima, T. Uchikoba, H. Yonezawa, M. Shimada, M. Kaneda, Cucumisin-like protease from the latex of Euphorbia supina, Phytochemistry 53 (2000) 639-644.

[5] N.G. Barnaby, F. He, X. Liu, K.A. Wilson, K.A. Wilson, A. TanWilson, Light-responsive subtilisin-related protease in soybean seedling leaves, Plant Physiol. Biochem. 42 (2004) 125-134.

[6] A.K. Batchelor, K. Boutilier, S.S. Miller, H. Labbé, L. Bowman, M. Hu, D.A. Johnson, M. Gijzen, B.L. Miki, The seed coat-specific expression of a subtilisin-like gene, SCS1, from soybean, Planta 211 (2000) 484-492.

[7] E.P. Beers, A.M. Jones, A.W. Dickerman, The S8 serine, C1 A cysteine and A1 aspartic protease families in Arabidopsis, Phytochemistry 65 (2004) 43-58.

[8] E.P. Beers, B.J. Woffenden, C. Zhao, Plant proteolytic enzymes: possible roles during programmed cell death, Plant Mol. Biol. 44 (2000) 399-415.

[9] V. Beilinson, O.V. Moshalenko, D.S. Livingstone III, R. Jung, N.C. Nielsen, Two subtilisin-like proteases from soybean, Physiol. Plant. 115 (2002) 585-597.

[10] D. Berger, T. Altmann, A subtilisin-like serine protease involved in the regulation of stomatal density and distribution in Arabidopsis thaliana, Genes Dev. 14 (2000) 1119-1131.

[11] A.M. Bogacheva, G.N. Rudenskaya, Y.E. Dunaevsky, G.G. Chestuhina, B.N. Golovkin, New subtilisin-like collagenase from leaves of common plantain, Biochimie 83 (2001) 481-486.

[12] T.-E. Chen, D.-J. Huang, Y.-H. Lin, Isolation and characterization of a serine protease from the storage roots of sweet potato (Ipomoea batatas [L.] Lam), Plant Sci. 166 (2004) 1019-1026.
[13] W.C. Coffeen, T.J. Wolpert, Purification and characterization of serine proteases that exhibit caspase-like activity and are associated with programmed cell death in Avena sativa, Plant Cell 16 (2004) 857873.

[14] E. Curotto, G. González, S. O’Reilly, G. Tapia, Isolation and partial characterization of a protease from Cucurbita ficifolia, FEBS Lett. 243 (1989) 363-365.

[15] M. Dryjanski, J. Otlewski, A. Polanowski, T. Wilusz, Serine protease from Cucurbita ficifolia seed; purification, properties, substrate specificity and action on native squash trypsin inhibitor (CMTI I), Biol. Chem. Hoppe Seyler 371 (1990) 889-895.

[16] B.M. Dunn, Determination of protease mechanism, in: R. Beynon, J.S. Bond (Eds.), Plant proteolytic enzymes-a practical approach, Oxford University Press, New York, 2001, pp. 77-79.

[17] Enzyme Nomenclature, Recommendations of the Nomenclature Committee of the IUBMB, Academic Press, San Diego, 1992.

[18] D. Fontanini, B.L. Jones, SEP-1—a subtilisin-like serine endopeptidase from germinated seeds of Hordeum vulgare L. cv, Morex, Planta 215 (2002) 885-893.

[19] V.J. Goodfellow, L.P. Solomonson, A. Oaks, Characterization of a maize root proteinase, Plant Physiol. 101 (1993) 415-419.

[20] U. von Groll, D. Berger, T. Altmann, The subtilisin-like serine protease SDD1 mediates cell-to-cell signaling during Arabidopsis stomatal development, Plant Cell 14 (2002) 1527-1539.

[21] A. Groover, A.M. Jones, Tracheary element differentiation uses a novel mechanism coordinating programmed cell death and secondary cell wall synthesis, Plant Physiol. 119 (1999) 375-384.

[22] F. James, R. Brouquisse, C. Suire, A. Pradet, P. Raymond, Purification and biochemical characterization of a vacuolar serine endopeptidase induced by glucose starvation in maize roots, Biochem. J. 320 (1996) 283-292.

[23] J.M.U. Hamilton, D.J. Simpson, S.C. Hyman, B.G. Ndimba, A.R. Slabas, Ara12 subtilisin-like protease from Arabidopsis thaliana: purification, substrate specificity and tissue localization, Biochem. J. 370 (2003) 57-67.

[24] L. Jordá, A. Coego, V. Conejero, P. Vera, A genomic cluster containing four differentially regulated subtilisin-like processing protease genes is in tomato plants, J. Biol. Chem. 274 (1999) 2360-2365.

[25] L. Jordá, V. Conejero, P. Vera, Characterization of P69E and P69F, two differentially regulated genes encoding new members of the subtilisin-like protease family from tomato plants, Plant Physiol. 122 (2000) 67-73.

[26] M. Kaneda, N. Tominaga, Isolation and characterization of a protease from the sarcocarp of melon fruit, J. Biochem. (Tokyo) 78 (1975) 1287-1296.

[27] M. Kaneda, T. Uchikoba, Protease from the sarcocarp of Tricosanthes bracteata, Phytochemistry 35 (1994) 583-586.

[28] M. Kaneda, H. Yonezawa, T. Uchikoba, Improved isolation, stability and substrate specificity of cucumisin, a plant serine endopeptidase, Biotechnol. Appl. Biochem. 22 (1995) 215-222.

[29] M. Kaneda, H. Yonezawa, T. Uchikoba, Purification and some properties of a protease from the sarcocarp of musk melon fruit, Biosci. Biotechnol. Biochem. 61 (1997) 2100-2102.

[30] C. Knorpp, C. Szigyarto, E. Glaser, Evidence for a novel ATPdependent membrane-associated protease in spinach leaf mitochondria, Biochem. J. 310 (1995) 527-531.

[31] E. Kobayashi, S. Sato, Y. Hotta, N. Miyajima, A. Tanaka, S. Tabata, Characterization of cDNAs induced in meiotic prophase in lily microsporocytes, DNA Res. 1 (1994) 15-26.

[32] L. Laplaze, A. Ribeiro, C. Franche, E. Duhoux, F. Auguy, D. Bogusz, K. Pawlowski, Characterization of a Casuarina glauca nodulespecific subtilisin-like protease gene, a homologue of Alnus glutinosa ag12, Mol. Plant Microb. Interact. 13 (2000) 113-117.

[33] X. Liu, Z. Zhang, N. Barnaby, K.A. Wilson, A. Tan-Wilson, Soybean subtilisin-like protease involved in initiating storage protein degradation, Seed Sci. Res. 11 (2001) 55-68. 
[34] J. Meichtry, N. Amrhein, A. Schaller, Characterization of the subtilase gene family in tomato (Lycopersicum esculentum Mill.), Plant Mol. Biol. 39 (1999) 749-760.

[35] M. Menon, P.J. Vithayathil, S.M. Raju, C.S. Ramadoss, Isolation and characterization of proteolytic enzymes from the latex of Synadenium grantii Hook, 'f', Plant Sci. 163 (2002) 131-139.

[36] D. Messdaghi, K. Dietz, Characterization of an extracellular chymostatin-sensitive serine protease preferentially expressed in young plant tissues, Biochim. Biophys. Acta 1480 (2000) 107-116.

[37] K. Müntz, M.A. Belozersky, Y.E. Dunaevsky, A. Schlereth, J. Tiedemann, Stored proteases and the initiation of storage protein mobilization in seeds during germination and seedling growth, J. Exp. Bot. 50 (2001) 1741-1752.

[38] K. Noda, M. Koyanagi, C. Kamyia, Purification and characterization of an endoprotease from melon fruit, J. Food Sci. 59 (1994) 585-587.

[39] O. Ostersetzer, S. Tabak, O. Yarden, R. Shapira, Z. Adam, Immunological detection of proteins similar to bacterial proteases in higher plant chloroplasts, Eur. J. Biochem. 236 (1996) 932-936.

[40] J.M. Palma, L.M. Sandalio, F.J. Corpas, M.C. Romero-Puertas, I. McCarthy, L.A. Río, Plant proteases, protein determination, and oxidative stress: role of peroxisomes, Plant Physiol. Biochem. 40 (2002) 521-530.

[41] J.B. Peltier, D.R. Ripoll, G. Friso, A. Rudella, Y. Cai, J. Ytterberg, L. Giacomelli, J. Pillardy, K.J. van Wijk, Clp protease complexes from photosynthetic and non-photosynthetic plastids and mitochondria of plants, their predicted three-dimensional structures, and functional implications, J. Biol. Chem. 279 (2004) 4768-4781.

[42] T. Popovič, V. Puizdar, J. Brzin, A novel subtilase from common bean leaves, FEBS Lett. 530 (2002) 163-168.

[43] K.M.R. Prasad, T.K. Virupaksha, Purification and characterization of a protease from jackfruit latex, Phytochemistry 29 (1990) 1763-1766.

[44] X. Qi, K.A. Wilson, A.L. Tan-Wilson, Characterization of the major protease involved in the soybean B-conglycinin storage protein mobilization, Plant Physiol. 99 (1992) 725-733.

[45] N.D. Rawlings, A.J. Barrett, Families of serine peptidases, Methods Enzymol. 244 (1994) 19-61.

[46] A. Ribeiro, A.D. Akkermans, A. van Kammen, T. Bisseling, K. Pawlowski, A nodule-specific gene encoding a subtilisin-like protease is expressed in early stages of actinorhizal nodule development, Plant Cell 7 (1995) 785-794.

[47] I.N. Roberts, P.F. Murray, C.P. Caputo, S. Passeron, A.J. Barneix, Purification and characterization of a subtilisin-like serine protease induced during the senescence of wheat leaves, Physiol. Plant 118 (2003) 483-490.

[48] G.N. Rudenskaya, A.M. Bogacheva, A. Preusser, A.V. Kuznetsova, Y.E. Dunaevsky, B.N. Golovkin, V.M. Stepanov, Macluralisin-a serine protease from fruits of Maclura pomifera (Raf.) Schneid, Planta 196 (1995) 174-179.

[49] G.N. Rudenskaya, A.M. Bogacheva, A. Preusser, A.V. Kuznetsova, Y.E. Dunaevsky, B.N. Golovkin, V.M. Stepanov, Taraxalisin-a serine protease from dandelion Taraxacum officinale Webb. S.l, FEBS Lett. 437 (1998) 237-240.

[50] J.D. Shannon, W. Wallace, Isolation and characterisation of peptide hydrolases from the maize root, Eur. J. Biochem. 102 (1979) 399-408.

[51] R.J. Siezen, J.A. Leunissen, Subtilases: the superfamily of subtilisinlike serine proteases, Protein Sci. 6 (1997) 501-523.
[52] H. Tanaka, H. Onouchi, M. Kondo, I. Hara-Nishimura, M. Nishimura, C. Machida, Y. Machida, A subtilisin-like serine protease is required for epidermal surface formation in Arabidopsis embryos and juvenile plants, Development 128 (2001) 4681-4689.

[53] A.L. Tan-Wilson, X. Liu, R. Chen, X. Qi, K.A. Wilson, An acidic amino acid-specific protease from germinating soybeans, Phytochemistry 42 (1996) 313-319.

[54] A.A. Taylor, A. Horsch, A. Rzepczyk, C.A. Hasenkampf, D.C. Riggs, Maturation and secretion of a serine protease is associated with events of late microsporogenesis, Plant J. 12 (1997) 1261-1271.

[55] N. Terp, K.K. Thomsen, I. Svendsen, A. Davy, D.J. Simpson, Purification and characterization of hordolisin, a subtilisin-like serine endoprotease from barley, J. Plant Physiol. 156 (2000) 468-476.

[56] P. Tornero, V. Conejero, P. Vera, Primary structure and expression of a pathogen-induced protease (PR-P69) in tomato plants: similarity of functional domains to subtilisin-like endoproteases, Proc. Natl. Acad. Sci. USA 93 (1996) 6332-6337.

[57] P. Tornero, V. Conejero, P. Vera, Identification of a new pathogeninduced member of the subtilisin-like processing protease family from plants, J. Biol. Chem. 272 (1997) 14412-14419.

[58] T. Uchikoba, K. Arima, M. Shimada, H. Yonezawa, M. Kaneda, Isolation and some properties of a serine protease from the fruits of Cudrania cochinchinensis (Lour.) Kudo et Masam, Biosci. Biotechnol. Biochem. 64 (2000) 623-624.

[59] T. Uchikoba, H. Horita, M. Kaneda, Proteases from the sarcocarp of yellow snake-gourd, Phytochemistry 29 (1990) 1879-1881.

[60] T. Uchikoba, S. Hosoyamada, M. Onjyo, K. Arima, H. Yonezawa, M. Kaneda, A serine endopeptidase from the fruits of Melothria japonica (Thunb.) Maxim, Phytochemistry 57 (2001) 1-5.

[61] T. Uchikoba, T. Niidome, I. Sata, M. Kaneda, Protease-D from the sarcocarp of honeydew melon fruit, Phytochemistry 33 (1993) 10051008 .

[62] T. Uchikoba, H. Yonezawa, K. Arima, M. Kaneda, Isolation and characterization of a serine protease from the sarcocarp of Cucumis metuliferus, J. Biochem. Mol. Biol. Biophys. 5 (2001) 251-259.

[63] T. Uchikoba, H. Yonezawa, M. Kaneda, Cleavage specificity of cucumisin, a plant serine protease, J. Biochem. (Tokyo) 117 (1995) 1126-1130.

[64] T. Uchikoba, H. Yonezawa, M. Kaneda, Cucumisin-like protease from the sarcocarp of Benincasa hispida var, Ryukyu, Phytochemistry 49 (1998) 2215-2219.

[65] P. Vera, J.H. Yago, V. Conejero, Immunogold localization of the citrus exocortis viroid-induced pathogenesis-related protease P69 in tomato leaves, Plant Physiol. 91 (1989) 119-123.

[66] Y.T. Wang, C.Y. Yang, Y.-T. Chen, Y. Lin, J.-F. Shaw, Characterization of senescence-associated proteases in postharvest broccoli florets, Plant Physiol. Biochem. 42 (2004) 663-670.

[67] H. Yamagata, S. Ueno, T. Iwasaki, Isolation and characterization of a possible native cucumisin from developing melon fruits and its limited autolysis to cucumisin, Agric. Biol. Chem. 53 (1989) 1009-1017.

[68] A. Yano, K. Suzuki, H. Shinshi, A signaling pathway, independent of the oxidative burst, that leads to hypersensitive cell death in cultured tobacco cells includes a serine protease, Plant J. 18 (1999) 105-109.

[69] Z.H. Ye, J.E. Varner, Induction of cysteine and serine proteases during xylogenesis in Zinnia elegans, Plant Mol. Biol. 30 (1996) 1233-1246.

[70] C. Zhao, B.J. Johnson, B. Kositsup, E.P. Beers, Exploiting secondary growth in Arabidopsis: construction of xylem and bark cDNA libraries and cloning of three xylem endopeptidases, Plant Physiol. 123 (2000) 1185-1196. 